\title{
A Case of Splenic Infarction Developing Atrial Fibrillation
}

\author{
Splenik Infarkt Gelişen Atrial Fibrilasyonlu Bir Olgu
}

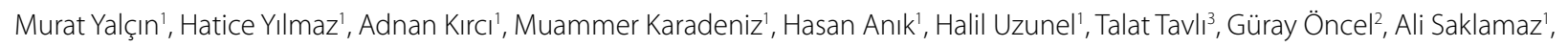
Nuh Yilmaz ${ }^{4}$

'Department of Internal Medicine, Şifa University Faculty of Medicine, İzmir, Turkey 2Department of Radiology, Şifa University Faculty of Medicine, İzmir, Turkey

${ }^{3}$ Department of Cardiology, Şifa University Faculty of Medicine, İmir, Turkey

${ }^{4}$ Department of Pediatrics, Dokuz Eylül University Faculty of Medicine, Izmir, Turkey

\section{ABSTRACT}

Introduction: Splenic infarct is an unusual altitude. Generally, it arises from hematologic diseases and vascular and thromboembolic disorders.

Case Report: A 79-year-old woman was admitted to our clinic with pain of the left upper region, emesis, vomiting, nausea, and cold sweat. The patient took beta-blocker and antiaggregant treatment for hypertension and atrial fibrillation. We detected rapid ventricular response atrial fibrillation on her ECG analysis. Also, abdominal CT was concordant with a splenic infarct. Her coagulation tests and sickle cell anemia tests were normal, which excluded hematological disorders (protein C, protein S, antithrombin III, Factor V Leiden mutation, homocysteine value, prothrombin 20210 A mutation, factor levels). We evaulated important risk factors as etiological causes for atrial fibrillation. Low-molecular-weight heparin (LMWH), oxygen, and intravenous hydration were started in the patient. Her complaints were decreased with time and showed clinical recovery.

Conclusion: Our case is very interesting, because there is no frequent splenic infarct coexisting with atrial fibrillation.

Keywords: Atrial fibrillation, abdominal pain, splenic infarction Received: 03.07.2013 Accepted:09.12.2013

\section{ÖZET}

Giriş: Splenik infarkt nadir görülen kritik bir durumdur. Genellikle hematolojik hastalıklar, vasküler ve tromboembolik bozukluklardan kaynaklanır.

Olgu Sunumu: Bu makalede 79 yaşında hipertansiyon ve atrial fibrilasyonu olan bir olgu sunulmuştur. Hasta antiagregan ve beta bloker tedavi alırken sol üst kadran ağrısı, bulantı, kusma ve soğuk terleme şikayeti ile acil servise başvurdu. Hastanın elektrokardiografisinde hızlı ventrikül yanıtlı atrial fibrilasyon tespit edildi. Batın tomografisi splenik infarkt ile uyumlu bulundu. Splenik infarkta yönelik yapılan tetkiklerde periferik yayma, koagülopati testleri (protein C, protein S, antitrombin III, Faktör $\checkmark$ Leiden mutasyonu, homosistein düzeyi, protrombin 20210 A mutasyonu, faktör düzeyleri) ve orak hücreli anemiye yönelik incelemelerin normal olması ile hematolojik hastalıklar ekarte edildi. Zeminde atrial fibrilasyon varlığı en güçlü etyolojik faktör olarak değerlendirildi. Hastaya oksijen, intravenöz hidrasyon ve düşük molekül ağırlıklı heparin başlandı. Hastanın şikayetleri azaldı, klinik olarak belirgin düzelme gözlendi.

Sonuç: Karın ağrısının nadir nedenlerinden biri olması ve etyolojik faktör olarak atrial fibrilasyon dışında patoloji saptanmaması nedeni ile olgumuzu literatür bilgileri eşliğinde sunduk.

Anahtar Kelimeler: Atriyal fibrilasyon, karın ağrısı, splenik infarkt Geliş Tarihi: 03.07.2013 Kabul Tarihi: 09.12.2013

\section{Giriş}

Splenik infarkt dalak damar tıkanıklığı sonrası gelişen parankimal iskemi ve doku nekrozunu ifade eder. İnfarkt segmental yada global olabilir. Splenik infarkt multifaktöriyel etkenlerin etiyolojide rol oynadığı, akut karın tablosunun nadir bir nedenidir. Etiyolojisinde en sık hematolojik hastalıklar, ikinci sıklıkta tromboembolik durumlar, daha nadir olarak da vasküler hastalıklar, anatomik bozukluklar ve kollagen doku hastalıkları bulunmaktadır (Tablo 1) (1, 2). Tromboemboliye sekonder gelişen splenik infarkt, hematolojik ve infeksiyöz hastalıklara bağlı olabileceği gibi, miyokard infarktüsü veya atrial fibrilasyonda görülen kan 
Tablo 1. Splenik infarkt nedenleri

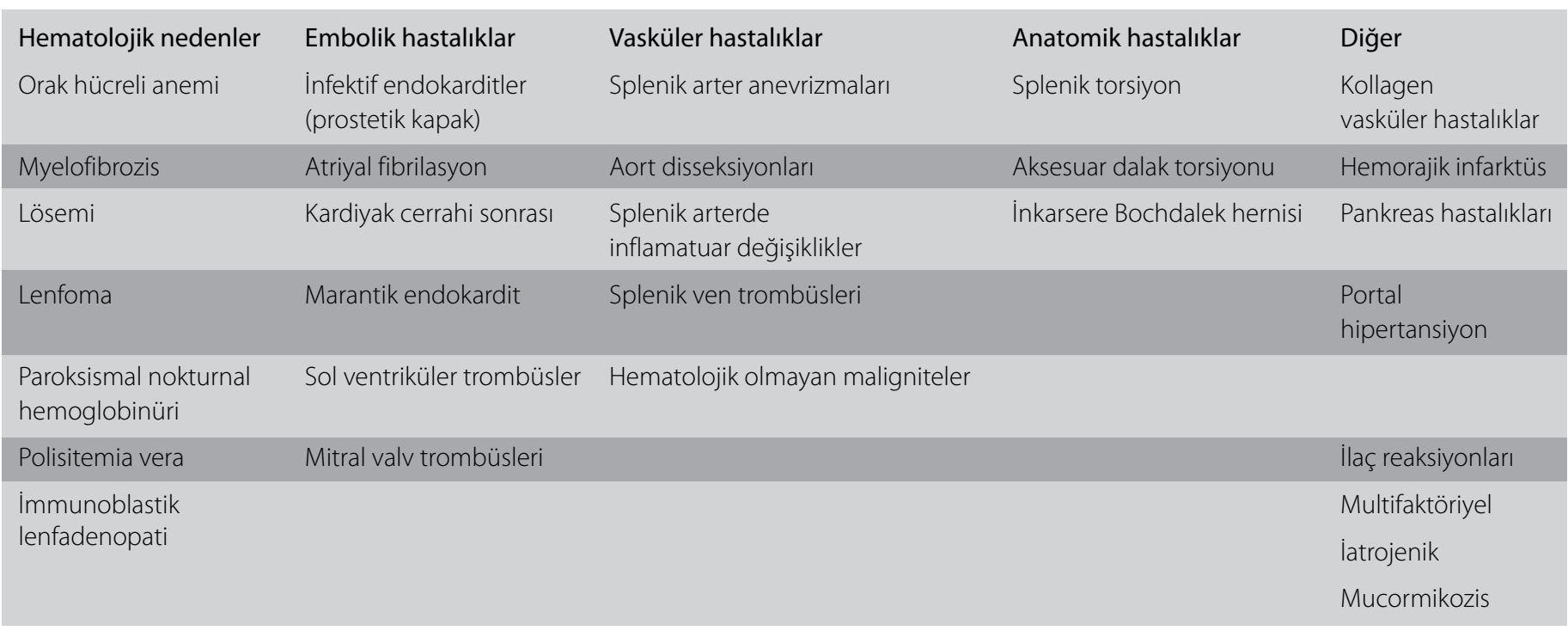

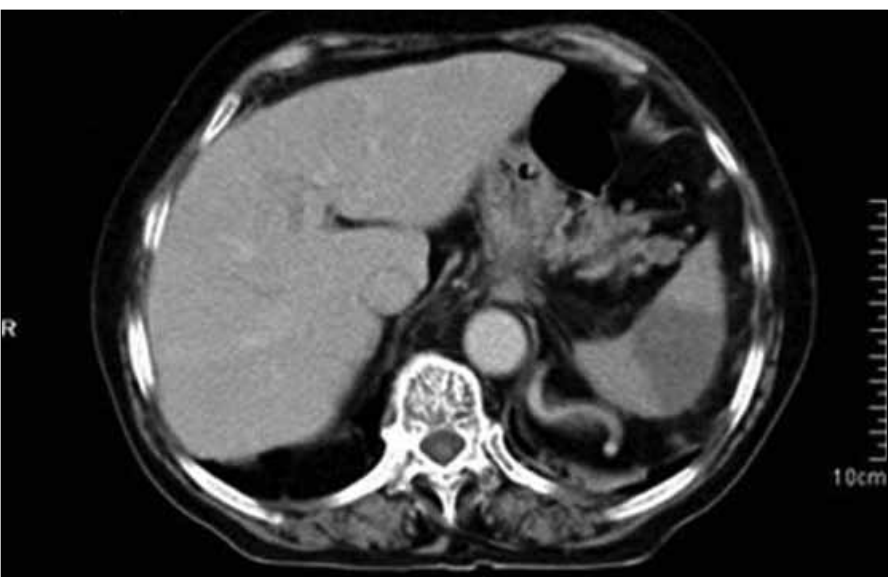

Resim 1. Olgunun Batın BT'sinde splenik infarkt görüntüsü

akım hızının azaldığı, buna bağlı olarak intrakardiyak trombüs oluşumuna zemin hazırlayan durumlarda da ortaya çıkabilmektedir. Atrial fibrilasyon (AF) zemininde gelişen splenik infarktlı olgumuzu karın ağrısının nadir nedenlerinden biri olması ve ayırıcı tanıda göz önünde bulundurulması nedeni ile sunduk.

\section{Olgu Sunumu}

79 yaşında bayan hasta, hipertansiyon ve AF nedeniyle beta bloker (metoprolol $50 \mathrm{mg}$ ) ve antiagregan (asetilsalisilik asit $100 \mathrm{mg}$ ) tedavi almaktayken, sol üst kadranda ani gelişen şiddetli karın ağrısı, bulantı, kusma ve soğuk terleme yakınmaları ile acil servise başvurdu. Sigara ve alkol kullanım öyküsü yoktu. Fizik muayenesinde soluk görünümde, soğuk terlemesi olan hastanın tansiyonu 180/110 mmHg, Nb: 100/dk, vücut ısısl: $36,5^{\circ} \mathrm{C}$ ölçüldü. Taşiaritmi, karın sol üst kadranda hassasiyet saptandı. Diğer sistem incelemeleri olağandı. Laboratuvar değerlerinde hemoglobin: 14,1 g/dL, hematokrit: \%41, MCV: 89fL, RBC: 4,68, trombosit: 292000/mm3, lökosit: 9400/mm3, kan açlık glukoz: 137 mg/dL, AST: 40 U/L, ALT $41 \mathrm{U} / \mathrm{L}$, BUN: 38mg/dL, kreatinin: 0,9 mg/dL, Na: 135 mmol/L, K: 3,6 mmol/L, idrar tahlili normal saptandı. Elektrokardiyografisinde hızlı ventrikül yanıtlı AF izlendi. Batın ultrasonografisinde (USG) patolojik bulguya rastlanmadı.
Bu bulgularla hasta izleme alındı. İzlemde ikinci gün ortaya çıkan subfebril ateş $\left(37,5^{\circ} \mathrm{C}\right)$ nedeni ile yapılan tetkiklerinde lökosit: 14900 / mm³, sedimantasyon: 27 mm/h, CRP: 22,3 mg/dL ve D-dimer:1.96ug/ $\mathrm{mL}$ saptandı. Yapılan ekokardiyografide kalp taşiaritmik, sol ventrikül fonksiyonları normal, biatrial genişleme, pulmoner hipertansiyon (sistolik PAB: $50 \mathrm{mmHg}$ ) saptandı. Intrakardiyak trombüs saptanmadı. Ayakta direkt batın grafisi (ADBG) ve tekrarlanan abdominopelvik USG'de patolojik bulguya rastlanmadı. Batın tomografisinde (BT) dalak anterosüperior ve inferior polünde erken ve geç kontrast fazlarında radyo opasitenin izlenmediği, posterior kesimde hipodens değişiklikler, dalak hilusunda aksesuar dalak, splenikarter akım dansitesinde düşüklükve distalde dolum defekti değişiklikleri görülerek, bulgular dalak infarktı ile uyumlu bulundu (Resim 1). Bakılan periferik yayma, koagülopati testleri, hemoglobin elektroforezi ve orak hücreli anemiye yönelik yapılan testlerde patolojik bulguya rastlanmadı. Hastaya oksijen, intravenöz (iv) hidrasyon, düşük moleküler ağırlıkı heparin, ampirik antibiyoterapi ve analjezik tedavi başlandı. Tedavinin 7. gününde semptomlar tamamen düzeldi ve tedavi 14 güne tamamlanarak hasta taburcu edildi.

\section{Tartışma}

Splenik infarkttın etyolojisinde birçok faktör sorumludur. Bu nedenler arasında tromboembolik olayların dalak dolaşımında tıkanıklık oluşturması (\%38), infiltratif hematolojik hastalıklar (\%29), splenik vasküler hastalıklar (\%6), anatomik bozukluklar (\%5) ve kollajen doku hastalıkları yer almaktadır $(1,2)$.

Infiltratif hematolojik hastalıklarda anormal hücreler tarafından dalak dolaşım tıkanıklığı olması ile infarkt oluşur. Örneğin, orak hücre hastalığında meydana gelen dalak infarktüsü asidoz ve hipoksi dönemlerinde olan anormal hemoglobin kristalleşmesine bağlıdır. Bu sert eritrositler dalak dolaşım tıkanıklığına neden olur $(3,4)$. Malign hematolojik hastalıklarda (KML gibi) anemi nedeniyle oksijen taşıma kapasitesi azaldığından, artan dalak kitlesine bağlı olarak meydana gelen oksijen gereksinimlerinde artış, enfarktüse yol açar.

Hiperkoagülabilite (malignite, antifosfolipid sendromu gibi) de dalak infarktüsüne neden olabilir(5). Örneğin, kalıtsal protein C 
eksikliğinin dalak infarktüsüne neden olduğu bildirilmiştir(4). Hastamızda periferik yayma ve koagülopati testleri (protein C, protein S, antitrombin III, FaktörV leiden mutasyonu, homosistein düzeyi, protrombin 20210 A mutasyonu, faktör düzeyleri) ve orak hücreli anemiye yönelik incelemelerin normal olması ile hematolojik hastalıklar ekarte edildi. Zeminde AF varlığı en güçlü etyolojik faktör olarak değerlendirildi (6).

Hastaların klinik muayenesinde en yaygın bulgu sol üst kadranda hassasiyet iken en sık görülen belirti, karın ya da sol yan ağrısıdır $(2,7)$. Ağrı hastaların yarısında bir haftadan az, diğer yarısında bir haftadan uzun sürelidir. Ektopik dalağın infarktı söz konusu ise ektopik dalağın lokalize olduğu bölgede ağrı meydana gelir (7). Ayrıca ateş ve titreme, bulantı ve kusma, plöretik göğüs ağrısı ve sol omuz ağrısı (Kehr işareti) görülebilir.

Hastamız ani başlayan şiddetli karın ağrısı ve tipik semptomlar ile başvurmuştur. Klasik kaynaklarda pseudokist ve abse formasyonu ile birlikte olan infarktlara, sıklıkla üst kadranda dolgunluk, ele gelen kitle ve plöretik semptomların eşlik ettiği vurgulanmaktadır (7). Küçük asemptomatik psödokistlerin $(<5 \mathrm{~cm})$ zamanla gerilemesi sözkonusu iken büyük dalak kistlerinin $(>5 \mathrm{~cm})$ rüptür riski yüksek olduğu için tedavi gerektirir (8).Septik tromboemboli, sepsis ve sol üst kadran ağrısı ile dalak absesine neden olabilir.

Hastaların laboratuar incelemesinde anemi, lökositoz ve trombositoz olduğu, ayrıca periferik yaymada Howell-Jolly cisimciklerinin görülebileceği bildirilmiştir (4). Bizim hastamızda hastaneye başvurusunun ikinci gününde lökositoz saptandı.

Splenik infarktlarda, ancak masif infarkt varsa ADBG'de; karın sol üst kadranda gaz ya da hava-SIVı seviyesi görülebilir. Batın USG'de erken dönemde bulguya rastlanmaz, en erken 24 saat sonra demarkasyon hattının oluşması ile tanıda yardımcı olabilir (9). Emboli düşünülen vakalarda özellikle Doppler USG tercih edilir. Intavenöz noniyonik kontrast ile yapılan BT'de; iyi sınırlı, kontrast tutmayan, hipodens alan görüntüsü ile \%75 tanı koydurucudur (9).Tercihen IV gadolinyum kontrast ile yapılan magnetik rezonans görüntüleme (MRG), infarkte dalak parankimini tanımlayan birbaşkayöntemdir. Kontrastlıçalışmalarda dalakçift kanakımı sebebiyle, erken dönemde lezyon oluşmayabilir, bu nedenle gecikmiş bir aşamasında yapılmalıdır. Batın USG'nin ilk 24 saatteki değerinin zayıf, kontrastlı görüntüleme yöntemlerinin ise daha üstün olduğu bildirilmektedir. Bununla uyumlu olarak hastamıza 24 saat arayla yapılan iki USG'de tanı konamamış, batın BT ile tanıya gidilebilmiştir. Teknesyum sintigrafisi ve anjiografinin \%90 diagnostik olduğu belirtilmesine rağmen hastamızda bu incelemeler yapılmamıştır (9).

Literatürde splenik infarkt tanısı koyulduktan sonra akut tablonun ve semptomların; hidrasyon, oksijen desteği, analjezi ve sıkı gözlem ile infarkt alanının büyüklüğüne bağlı olarak 7 ile 14 gün arasında gerileyebileceği gösterilmiştir (1).Komplikasyonsuz vakalarda medikal tedavi başarısının yüksek olduğu bildirilmiştir. Bizim hastamızda da medikal tedaviye yanıt alınması literatürü desteklemektedir.

Splenik infarktlı hastaların \%20'sinde splenik abse, hemoraji, rüptür ve pseudokist oluşumu gibi komplikasyonlar ortaya çıkabilir. Tekrarlayan semptomları olan hastalarda, komplikasyon gelişmesi durumunda ve hematolojik sepsis ve septik embolide splenektomi endikedir. Hastaların 1/3'ünde splenektomi endikasyonu vardır (1). Komplikasyonsuz asemptomatik infarkt cerrahi müdahale gerektirmez. Biz hastamızın yakınmasının ilk defa olması ve komplike olmaması nedeniyle splenektomi uygulamadık.

\section{Sonuç}

Splenik infarkt ani gelişen şiddetli sol üst kadran ağrısının nadir bir nedenidir ve medikal tedavi ile tam düzelme şansı olan, hatırda bulundurulması gereken önemli bir klinik durumdur.

Informed consent: Informed consent was obtained from the patient.

Peer-review: Externally peer-reviewed.

Author contributions: Concept - N.Y.; Design - M.Y.; Supervision M.K., A.S.; Data Collection and/or Processing - H.A., A.K.; Analysis and/ or Interpretation - H.Y.; Writer - M.Y.; Critical Review - H.U., T.T., G.Ö.

Conflict of interest: The authors declared that there is no conflict of interest.

Financial Disclosure: The authors declared that this study received no financial support.

Hasta Onamı: Hasta onamı hastadan alınmıştır.

Hakem değerlendirmesi: Dış bağımsız.

Yazar Katkıları: Fikir - N.Y.; Tasarım - M.Y.; Denetleme - M.K., A.S.; Veri toplanması ve/veya işlemesi - H.A., A.K.; Analiz ve/veya yorum - H.Y.; Yazıyı yazan - M.Y.; Eleştirel İnceleme - H.U., T.T., G.Ö.

Çıkar Çatışması: Yazarlar herhangi bir çıkar çatışması bildirmemişlerdir.

Finansal Destek: Bu çalışma için finansal destek alınmamıştır.

\section{Kaynaklar}

1. Jaroch TM, A. Broughan T, Hermannn ER: The natural history of splenic infarction. Surgery 1986; 100: 743-50.

2. Antopolsky M, Hiller N, Salameh S,Goldshtein B, Stalnikowicz R. Splenic infarction: 10 years of experience. Am J Emerg Med 2009; 27: 262-5. [CrossRef]

3. Ebert EC, Nagar M, Hagspiel KD. Gastrointestinal and hepatic complications of sickle cell disease. Clin Gastroenterol Hepatol 2010; 8: 483-9. [CrossRef]

4. Park MY, Kim JA, Yi SY, Chang SH, Um TH, Lee HR. Splenic infarction in a patient with autoimmune hemolytic anemia and protein $\mathrm{C}$ deficiency. Korean J Hematol 2011; 46: 274-8. [CrossRef]

5. Görg C, Seifart U, Görg K. Acute, complete splenic infarction in cancer patient is associated with a fatal outcome. Abdomen Imaging 2004; 29: 224-7. [CrossRef]

6. Menke J, Luthje L, Kastrup A, Larsen J. Thromboembolism in atrial fibrillation. Am J Cardiol 2010; 105: 502-10. [CrossRef]

7. Lawrence YR, Pokroy R, Berlowitz D, et al. Spleni cinfarction: an update on William Osler's observations. Isr Med Assoc J 2010; 12: 362-5.

8. Pachter HL, Hofstetter SR, Elkowitz A. Traumaticcysts of the spleen-the role of cystectomy and splenic preservation: experience with seven consecutive patients. J Trauma Sep 1993; 35: 430-6. [CrossRef]

9. Robertson F, Leander P, Ekberg O. Radiology of the spleen. European Radiol 2001; 11: 80-95. [CrossRef] 